\title{
Hegemonista maskuliinisuutta etsimässä
}

R.W. Connell (2005). Masculinities. University of California Press.

MIES- ja maskuliinisuustutkimuksen viitatuin tutkija on australialainen Raewyn (ent. R.W.) Connell. Erityisesti sukupuolta ja koulutusta käsittelevästä tuotannosta tunnetun Sydneyn yliopiston professorin (tiede)maailman laajuinen läpimurtoteos oli vuonna 1995 ensijulkaisunsa saanut Masculinities.

Alkuperäisen teoksen 16 vuoden takaisesta ilmestymisestä huolimatta teos on edelleen ajankohtainen - Google Scholar -tietokannan mukaan teokseen kohdistetuista 3500 viittauksesta yli puolet on tehty vuoden 2005 jälkeen - jonka lisäksi sitä on käännetty yhä 2000-luvulla useille kielille. Käsissämme oleva, uusittu englanninkielinen painos julkaistiin vuonna 2005.

Tässä tekstissä keskitymme erityisesti kirjan myötä esille nostettuun hegemonisen maskuliinisuu- den käsitteeseen. Vaikka Connell on työskennellyt käsitteen parissa jo 1980-luvulta alkaen ${ }^{1}$, suurimman huomionsa se on saanut vasta Masculinities-teoksen myötä. Kyseessä on yksi keskeisimmistä ja käytetyimmistä mies- ja maskuliinisuustutkimuksen käsitteistä.

Vuoden 2005 painos muodostuu kolmesta ensimmäisen painoksen osasta sekä Connellin kirjoittamasta uudesta johdantoluvusta. Ensimmäisessä osassa Connell esittelee maskuliinisuustutkimuksen keskeisimmät suuntaukset tarkastellessaan muun muassa maskuliinisuuden sosiaalista luonnetta ja maskuliinisuustutkimuksen historiaa. Toinen osa koostuu neljästä tutkimuskuvauksesta viimeisen keskittyessä maskuliinisuuden historialliseen luonteeseen ja miehuuden politiikkoihin.

\section{MASKULIINISUUS VUOROVAIKUTUKSEN PIIRTEENÄ}

Lähtökohta on selvä - sosiaalikonstruktivistina tunnetun Connellin mukaan maskuliinisuus ja feminiinisyys eivät perustu sukupuolten "luonnollisiin" ominaisuuksiin, vaan hän näkee ne piirteinä, joita liitetään sukupuoliin sosiaalisessa vuorovaikutuksessa.

Teoksen alussa Connell kuvaa, kuinka yleiseen konstruktivistiseen maskuliinisuus- ja sukupuolikäsitykseen on päädytty kolmiportaisesti. Ensimmäinen yritys maskuliinisuuden tieteellistämiseen tapahtui psykoanalyyttisen tutkimuksen piirissä, jonka jälkeen maskuliinisuuksien tutkimus siirtyi sosiaalipsykologisten sukupuolirooliteorioiden piiriin. Nykyistä yhteiskuntatieteellistä maskuliinisuuksien tutkimuksen 


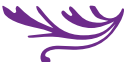

paradigmaa hallitsee sosiaalikonstruktivistinen ymmärrys sukupuolesta.

Connell korostaa, kuinka maskuliinisuudet ovat aina kulttuurija tilannesidonnaisia sekä muodostuvat suhteessa kulttuurisiin feminiinisyyksiin. Tilannesidonnaista maskuliinisuutta hän kuvaa maskuliinisuuksien kulttuurisella repertuaarilla, josta yksilö voi valita kulloiseenkin tilanteeseen sopivan käyttäytymismallin. Näin ollen yksilö voi eri tilanteissa toimia "kuin mies" tai esiintyä lastaan hoivaavana isänä. Maskuliinisuuksien kulttuurisidonnaisuutta Connell alleviivaa toteamalla kuinka esimerkiksi maskuliinisuuden käsitettä ei kaikissa kulttuureissa tunneta.

Purkaessaan kulttuurillista konstruktiota yhtenäisestä ja "luonnollisesta" maskuliinisuudesta Connell hahmottelee viitekehyksen, jossa hän kuvaa neljää (karikatyyristä) toistensa kanssa vuorovaikutuksessa olevaa maskuliinisuuden muotoa. Nämä ovat hegemoninen (hegemony), alisteinen (subordination), myötämielinen (complicity) ja marginalisoitu (marginalization) maskuliinisuus.

Yhteiskuntatieteellisissä diskursseissa vakiintuneella, mutta kiistanalaisella hegemonisen maskuliinisuuden käsitteellä Connell tarkoittaa (ajan ja paikan suhteen vaihtuvan) valtakulttuurin hyväksymää maskuliinisuuden konstruktiota, joka hallitsee käsityksiä normaaleista ja järkevistä tavois- ta "olla mies". Yhteiskunnallista ylivaltaa ja hallintaa kuvaavaan gramscilaiseen hegemonia-käsitteeseen viittaavaa konstruktiota voidaan ymmärtää sukupuolittuneiden käytäntöjen nivoutumana, jotka pitävät yllä patriarkaalisen vallan oikeutusta sekä miessukupuolen hallitsevaa asemaa.

Alisteisiksi maskuliinisuuksiksi (euroamerikkalaisessa viitekehyksessä) Connell nimeää muun muassa homoseksuaalisten miesten maskuliinisuuden - hegemonisessa viitekehyksessä homoseksuaalisuus vertautuu feminiinisyyteen.

Myötämielisiksi maskuliinisuuksiksi Connell määrittelee ne maskuliinisuuksien muodot jotka eivät edusta hegemoniaa, mutta hyötyvät siitä "patriarkaalisen osingon" - muun muassa korkea yhteiskunnallinen asema tai parempi palkka - kautta. Myötämielisiä maskuliinisuuksia edustavat miehet muodostavat Connellin mukaan kenties suurimman maskuliinisuuksien ryhmän, sillä suurin osa esimerkiksi perheitään ja vaimojaan rakastavista, kunnioittavista ja väkivallattomista miehistä saa kuitenkin osuutensa patriarkaalisesta osingosta.

Marginalisoiduiksi Connell nimeää muun muassa yhteiskuntaluokan tai etnisen taustan pohjalta hegemonisuudesta eroavat maskuliinisuudet.

Hegemonisen maskuliinisuuden kiistanalaisuutta kuvaa sen kohtaama kritiikki, joka on kohdistunut muun muassa käsitteelli- seen epäselvyyteen ja monitulkintaisuuteen ${ }^{2}$. Sitä, mihin maskuliinisuuden käsitteellä ylipäätänsä viitataan, on pidetty epäselvänä - Connellin mukaan neljä keskeisintä ja toisistaan keskeisesti poikkeavaa tapaa määritellä maskuliinisuutta ovat essentialistinen, positivistinen, normatiivinen ja semioottinen. Myös käsitteeseen liitetty heteronormatiivisuus on saanut kritiikkiä, sillä sen on nähty oikeuttavan ja hyväksyttävän miesten ja naisten välisiä eroavaisuuksia.

Maskuliinisuuden käsitteen voidaan nähdä myös unohtavan sukupuolien sisäiset erot keskittyessään sukupuolten välisiin eroihin. Hegemonisen maskuliinisuuden käsitteellistä monitulkintaisuutta kuvaa kysymys siitä, kuka edustaa hegemonista maskuliinisuutta - Marlboromiehet, elokuvatähdet, urheilijat vai huippujohtajat? Esimerkiksi sosiaalinen valta ei yksistään riitä täyttämään hegemonisen maskuliinisuuden ideaalia. Käsitettä on kritisoitu myös sen kohtaamattomuudesta "miesten eletyn elämän” kanssa, jonka lisäksi sen on nähty tuottavan yksinkertaistuksia sukupuolten välisistä suhteista.

\section{LÄNSIMAISEN MASKULIINISUUDEN KOLONISAATIO}

Sittemmin, Masculinitiesin julkaisun jälkeen, Connell on jatkanut hegemonisen maskuliinisuuden käsitteellistämistä esitetyn 


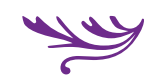

kritiikin pohjalta ${ }^{3}$. Hän puoltaa yhä käsitteen merkitysten moninaisuutta, sillä ymmärrys useista erilaisista maskuliinisuuksista on yleisesti hyväksytty miestutkimuksen parissa. Connellin mukaan hegemonisen maskuliinisuuden ei tarvitse myöskään ilmetä jokapäiväisessä elämässä tyypillisimpänä piirteenä poikien ja miesten keskuudessa. Hegemonia toimii pikemminkin esimerkkien tuottamina, kuten urheilusankareiden tai rock-tähtien muodossa. Näin hegemonia on ideaalinen malli, jota miehet ja pojat noudattavat vaihtelevissa mittasuhteissa.

Sen sijaan Connell toteaa, että ymmärrys sosiaalisista suhteista on liian yksinkertainen ja hän korostaa tarvetta laajempaan ymmärrykseen sukupuolihierarkioista. Ongelmalliseksi Connell näkee myös yleisen tulkinnan maskuliinisuuksista piirreteorian kaltaisena piirteiden kokoelmana, joiden myötä maskuliinisuuksia voidaan tarkastella kiinteiden tunnuspiirteiden myötä. Yhdeksi käsitteen keskeiseksi kehityskohteeksi Connell onkin nostanut ymmärryksen "maskuliinisuuksien maantieteestä". Hän toteaa että maskuliinisuuden suurin murros ei ole esimerkiksi "länsimaisen maskuliinisuuden pehmeneminen", vaan sen kolonisaatio - länsimaisen maskuliinisuuden laajentuminen globaaliksi maskuliinisuudeksi.
Kun Masculinitiesin ensipainoksesta on kulunut puolitoista vuosikymmentä, on helppo havaita teoksen saavuttama arvostettu mutta kiistelty asema sekä yhteiskuntatieteellisessä mies- ja maskuliinisuus- että sukupuolentutkimuksessa yleisestikin ottaen. Näyttää siltä, että teos tulee myös pitämään asemansa kiistanalaisena "uutena klassikkona". Samanaikaisesti sen kuvamaat käsitteet, kuten hegemoninen maskuliinisuus, ovat kuitenkin jatkuvassa merkitysten läpivirtauksessa, muuttuen asiayhteyden, ajan ja paikan mukana. Tämä korostaa kyseisten käsitteiden ja sisältöjen merkitysten ymmärtämisen ja kriittisen tarkastelun merkitystä myös jatkossa.

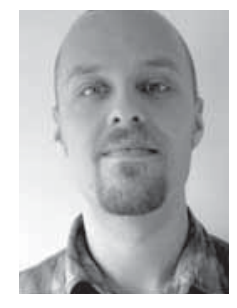

Petteri Eerola

KM, tohtorikoulutettava Kasvatustieteiden laitos Jyväskylän yliopisto

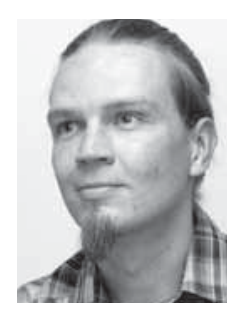

Teemu Kuosmanen YTM, jatko-opiskelija yhteiskuntatieteiden ja filosofian laitos Jyväskylän yliopisto
${ }^{1}$ Ks. esim. seuraavat teokset:

Kessler, S. J., Ashenden, D. J., Connell, R.W. \& Dowsett, G. W. 1982. Ockers and discomaniacs. Sydney: Inner City Education Center.

Carrigan, T., Connell, R.W. \& Lee, J. 1985. Toward a new sociology of masculinity. Theory and Society 14 (5), 551-604.

Connell, R.W. 1987. Gender and power. Sydney: Allen and Unwin.
Connell ja James Messerschmidt ovat pohtineet käsitteen kohtaamaa kritiikkiä yksityiskohtaisesti artikkelissa: Connell, R.W. \& Messerschmidt, J. 2005. Hegemonic masculinity. Rethinking the concept. Gender \& Society 19 (6), 829-859

Connell, R.W. \& Messerschmidt, J. 2005. Hegemonic Masculinity. Rethinking the Concept. Gender \& Society 19 (6), 829-859. 